\title{
PEMBUATAN MAKET GEOLOGI STRUKTUR SEBAGAI BAHAN AJAR DI JURUSAN TEKNIK KEBUMIAN FAKULTAS SAINS DAN TEKNOLOGI UNIVERSITAS JAMBI
}

\author{
Bagus Adhitya ${ }^{1}{ }^{*}$, Hari Wiki Utama ${ }^{1}$, Anggi Deliana Siregar ${ }^{1}$, Magdalena Ritonga ${ }^{1}$, \\ Yulia Morsa Said ${ }^{1}$ \\ ${ }^{1}$ Universitas Jambi, Jambi, Indonesia \\ *bagusadhitya@unja.ac.id
}

\begin{abstract}
Abstrak: Geologi Struktur adalah salah satu mata kuliah yang ada pada kurikulum Program Studi Teknik Geologi, Teknik Pertambangan dan Teknik Geofisika yang dikelola oleh Jurusan Teknik Kebumian. Mata kuliah ini mempelajari bentukan atau struktur batuan penyusun kerak bumi, arsitektur batuan penyusun kerak bumi, dan bagaimana proses pembentukan struktur geologi. Identifikasi masalah yang ditemui adalah belum optimalnya hasil pembelajaran pada mata kuliah geologi struktur pada masa pandemi karena tidak adanya alat praktikum yang dapat digunakan untuk menggantikan kegiatan observasi lapangan. Di sisi lain observasi lapangan terhadap struktur geologi secara langsung sulit untuk dilaksanakan dan memiliki resiko yang cukup besar. Solusi dari permasalahan tersebut adalah dilakukan pembuatan maket geologi struktur taman bumi (Geopark) Merangin, Jambi. Kegiatan pengabdian kepada masyarakat ini bertujuan untuk membuat maket geologi struktur sebagai bahan ajar yang dapat menjadi alternatif pembelajaran dan praktikum pengukuran struktur dasar di masa pandemi Covid-19. Metode yang digunakan dalam menyelesaikan permasalahan mitra adalah metode problem solving. Dari hasil pengukuran strike \& dip diperoleh kedudukan pada sayap kiri lipatan maket geologi struktur berarah $\mathrm{N} 218^{\circ} \mathrm{E} / 38^{\circ}$ (Barat Daya) sedangkan pada sayap

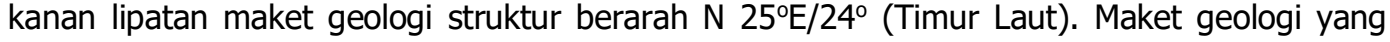
dibuat memiliki struktur berupa antiklin dengan bagian tengah mengalami pergeseran karena struktur sesar. Hasil analisis data struktur sesar merupakan sesar mendatar naik kanan, dengan kedudukan bidang sesar $\mathrm{N} 42^{\circ} \mathrm{E} / 66^{\circ}$, Plunge/Bearing $80^{\circ} \mathrm{N} 87^{\circ} \mathrm{E}$, dan Rake $45^{\circ}$. Pembuatan maket geologi struktur sangat bemanfaat dalam menambah pemahaman mahasiswa pada mata kuliah geologi struktur. Mahasiswa dapat mengetahui pengukuran struktur dasar sebelum terjun ke lapangan secara langsung sehingga mereka akan lebih siap saat melakukan kuliah lapangan.
\end{abstract}

Kata Kunci: maket geologi struktur, bahan ajar, geopark Merangin

\begin{abstract}
Structural Geology is one of the courses in the curriculum of Geological Engineering, Mining Engineering, and Geophysical Engineering managed by the Department of Earth Engineering. This course studies the formation or structure of the rocks that make up the earth's crust, the architecture of the rocks that make up the earth's crust, and how the geological structure is formed. The problems identified were the non-optimal learning outcomes in the structural geology course during the pandemic and the absence of practical tools that can be used for field observation activities. On the other hand, field observations of geological structures directly are very difficult to carry out and have great risks. The solution to this problem is to make a geological structure scale model of the Earth Park (Geopark) Merangin, Jambi. This community service program aims to create structural geology mockups as teaching materials that can be alternative learning and practicum for measuring basic structures during the Covid-19 pandemic. The method used in this program was problem-solving. From the result of the strike and dip measurement, the position was obtained on the left-wing of the geological model fold of the structure withN N 2180E/380 direction (Southwest). While on the right-wing of the geological model fold of the structure, the direction was N 2180E/380 (Northeast). The developed geological scale model has a structure in the form of an anticline with the center shifting due to the fault. Data analysis resulted in the position of the fault plane $N 42^{\circ} \mathrm{E} / 66^{\circ}$, Plunge/Bearing $80^{\circ} \mathrm{N} 87^{\circ} \mathrm{E}$, and Rake $45^{\circ}$. Making a structural geology scale model is very useful in increasing students' understanding of the structural geology course. They can know the measurement of basic structures before going to the field directly so that the students will be better prepared when doing the field trip.
\end{abstract}

Keywords: structural geology mockup, teaching materials, merangin geopark 


\section{Pendahuluan}

Mata kuliah Geologi Struktur adalah salah satu mata kuliah wajib di Program Studi Teknik Geologi, Teknik Pertambangan dan Teknik Geofisika, Universitas Jambi. Mata kuliah ini mempelajari bentukan atau struktur batuan penyusun kerak bumi, arsitektur batuan penyusun kerak bumi, dan bagaimana proses pembentukan struktur geologi. Geologi struktur mulai berkembang dari ilmu yang deskriptif menjadi bersifat kuantitatif untuk mengetahui proses pembentukan dan proses deformasi geologi pada batuan (Twiss dan Moore, 1992). Geologi struktur bergantung pada observasi batuan yang telah terdeformasi di lapangan yang ditemukan pada singkapan. Struktur geologi modern banyak melakukan simulasi matematika maupun laboratorium (Davis dan Reynolds, 1996, Twiss dan Moore, 1992). Dengan mempelajari proses geologi dan pembentukan struktur geologi, mahasiswa dapat mengetahui keadaan morfologi bumi yang dapat mendukung analisa kesesuaian dan kestabilan suatu kawasan terhadap daya dukung lahan untuk kegiatan konstruksi bangunan. Menurut Sunan \& Gibran (2019), dengan mempelajari geologi struktur mahasiswa dapat mengetahui daerah yang berpotensi memiliki sumberdaya geologi, kemenerusan serta pola sebaran dari sumberdaya geologi tersebut, dan bagaimana tingkat kestabilan suatu wilayah terhadap resiko bencana longsor. Permasalahan yang dihadapi di Jurusan Teknik Kebumian khususnya pada mata kuliah Geologi Struktur berupa kurang optimalnya kegiatan perkuliahan dan praktikum geologi struktur dikarenakan minimnya peralatan praktikum, jauhnya jarak lapangan tempat observasi struktur geologi, serta adanya pandemi Covid-19 yang mengharuskan mahasiswa dan dosen menerapkan protokol kesehatan dan melakukan swab antigen saat pergi dan pulang dari lapangan agar dapat memutus rantai penyebaran Covid-19 (Wiratmo, 2020).

Pada praktek di lapangan, sangat banyak mahasiswa Jurusan Teknik Kebumian yang masih mengalami kebingungan dalam membedakan sesar dan kekar ataupun antiklin dan sinklin di lapangan. Juga masih banyak sekali mahasiswa yang tidak tahu bagaimana cara mengukur dan menganalisis kedudukan bidang batuan, bidang sesar, kekar, dan zona breksiasi. Oleh karena itu perlu persiapan sebelum mahasiswa melakukan pengukuran langsung di lapangan. Bukan hanya persiapan materi dan teori tapi juga aplikasi pengukuran pada model struktur geologi. Selain pengamatan secara langsung, struktur geologi yang ada di permukaan dapat diidentifikasi dengan aplikasi penginderaan jauh (Azhar, Maryanto \& Rachmansyah, 2016), sedangkan untuk melihat struktur geologi di bawah permukaan dapat dianalisis dengan menggunakan metode geofisika (Patya et al., 2018)

Berdasarkan permasalahan yang dihadapi di Jurusan Teknik Kebumian khususnya pada mata kuliah Geologi Struktur berupa kurang optimalnya kegiatan perkuliahan dan praktikum geologi struktur dikarenakan minimnya peralatan praktikum, jauhnya jarak lapangan tempat observasi struktur geologi, serta adanya pandemi Covid-19 maka solusi yang ditawarkan pada kegiatan pengabdian ini adalah Pembuatan Maket Geologi Struktur Sebagai Bahan Ajar di Jurusan Teknik Kebumian Fakultas Sains Dan Teknologi Universitas Jambi. 


\section{Metode}

Pelaksanaan pembuatan Maket Geologi Struktur di Jurusan Teknik Kebumian, Fakultas Sains dan Teknologi, Universitas Jambi dilaksanakan pada tanggal 27 Agustus 2021 - 10 September 2021. Kegiatan pengabdian kepada masyarakat ini menggunakan metode problem solving. Metode ini akan melatih pendidik dan peserta didik untuk menganalisa masalah yang terjadi dan memberikan solusi dari permasalahan tersebut (Anggreini et al., 2020). Langkahlangkah yang dilakukan untuk menyelesaikan permasalahan mitra meliputi: identifikasi permasalahan dan kebutuhan mitra (Jurusan Teknik Kebumian), dimana permasalahan yang dihadapi mitra adalah kurangnya peralatan praktikum, jauhnya jarak lapangan yang bisa digunakan untuk pengukuran struktur, dan adanya pandemic Covid-19 yang menyebabkan sulitnya untuk kegiatan observasi lapangan. Solusi yang diberikan untuk menyelesaikan permasalahan mitra adalah pembuatan maket geologi struktur. Dimana diawali dengan pengurusan izin pembangunan Maket Geologi Struktur di Taman Fakultas Sains dan Teknologi, pembuatan design Maket Geologi Struktur menggunakan aplikasi Coreldraw, pembuatan maket geologi struktur, dan pelatihan pengukuran struktur kepada dosen dan asisten praktikum mata kuliah geologi struktur. Gambaran langkah-langkah kegiatan Pengabdian Kepada Masyarakat dapat dilihat pada Gambar 1.

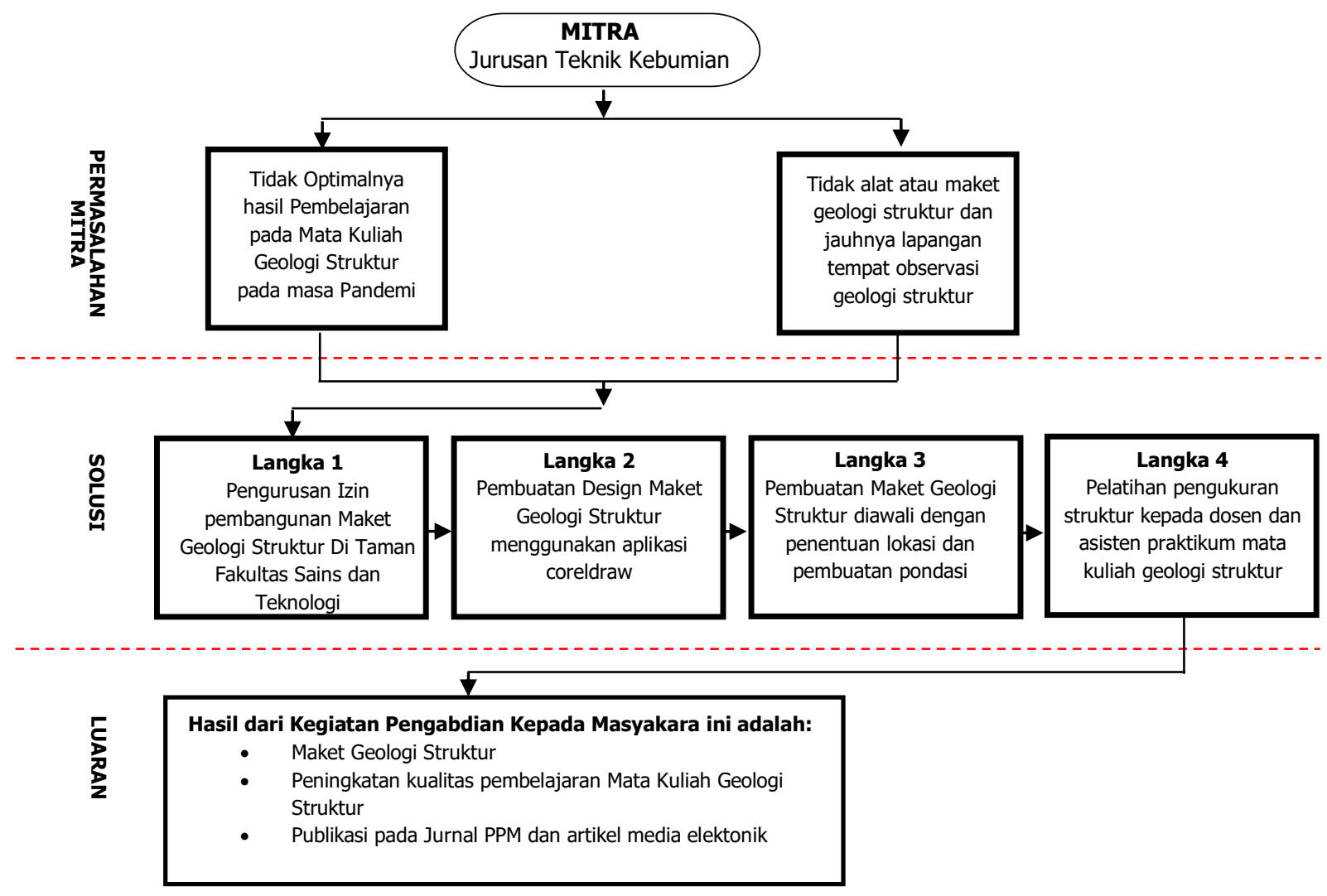

Gambar 1. Kerangka Pemecahan Masalah dalam Kegiatan PPM Jurusan Teknik Kebumian 


\section{Hasil dan Pembahasan}

Pembuatan maket ini diawali dengan pengurusan izin pembangunan maket dari pihak Fakultas dan pembuatan design dari maket yang merepresentasikan bentuk kondisi alam bebatuan di Taman Bumi (geopark) Merangin, Jambi (Gambar 2). Taman Bumi Merangin merupakan salah satu geopark nasional di Indonesia yang sedang diajukan ke tingkat yang lebih tinggi sebagai Unesco Global Geopark (UGG) (Ritonga et al., 2018).

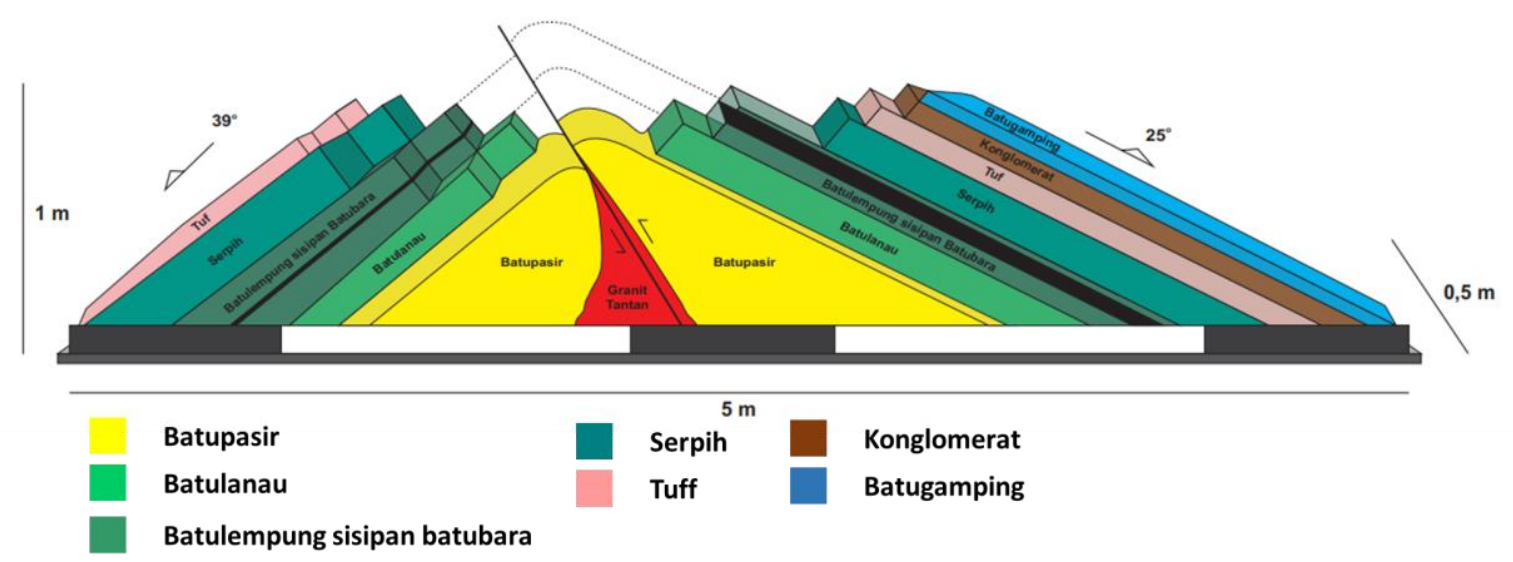

Gambar 2. Design Maket Geologi Struktur Taman Bumi (Geopark) Merangin, Jambi menggunakan aplikasi CorelDraw

Maket geologi struktur yang dibuat oleh tim PPM Prodi Teknik Geologi merepresentasikan litologi batuan yang ada di geopark Merangin, khususnya pada Formasi Merangin (Pm) dan Formasi Granitoid Tantan (TrJgd). Formasi Mengkarang berumur Permian yang merupakan Formasi tertua kedua setelah Formasi Ngaol (PCn). Batuan penyusun Formasi Mengkarang terdiri dari batu pasir, batu lanau, batu lempung sisipan batu bara, serpih, tuf, konglomerat, dan batu gamping. Selanjutnya seluruh batuan penyusun Formasi Mengkarang ini diintrusi oleh Formasi Granitoid Tantan yang berumur Trias hingga Jura (Utama et al., 2018).

Proses pembuatan maket geologi struktur dilanjutkan dengan penentuan lokasi pembuatan maket. Proses ini perlu dilakukan dengan teliti supaya hasil akhir tidak hanya melihat fungsi tapi juga tetap mementingkan estetika. Pembuatan maket ini berada di lokasi taman depan bagian Timur dari Fakultas Sains dan Teknologi. Proses pembuatan Maket Geologi Struktur dapat dilihat pada Gambar 3. Setelah dilakukan pengukuran, selanjutnya dilanjutkan tahap pembangunan pondasi dari maket yang akan dibuat. Hal ini bertujuan supaya maket geologi struktur yang dibuat kuat dan mampu digunakan dalam jangka waktu yang lama. Tahap selanjutnya adalah pembuatan layer atau lapisan batuan, dimana pada sayap kiri lipatan terdiri dari lima lapisan batuan dan sayap kanan terdiri dari tujuh lapisan batuan. Pada bagian tengah dari maket terlihat adanya intrusi dari batuan beku Formasi Granitoid Tantan yang diakibatkan adanya zona lemah berupa sesar. Setelah dilakukan proses penyelesaian berupa pemberian tekstur batuan dan pengecatan litologi batuan, tahap terakhir dari proses pembuatan ini adalah penyerahan serta peresmian maket geologi struktur oleh Ketua Pengabdian Hari Wiki Utama, S.T., M.Eng. kepada Ketua Jurusan Dr. Lenny Marlinda, ST, MT. 


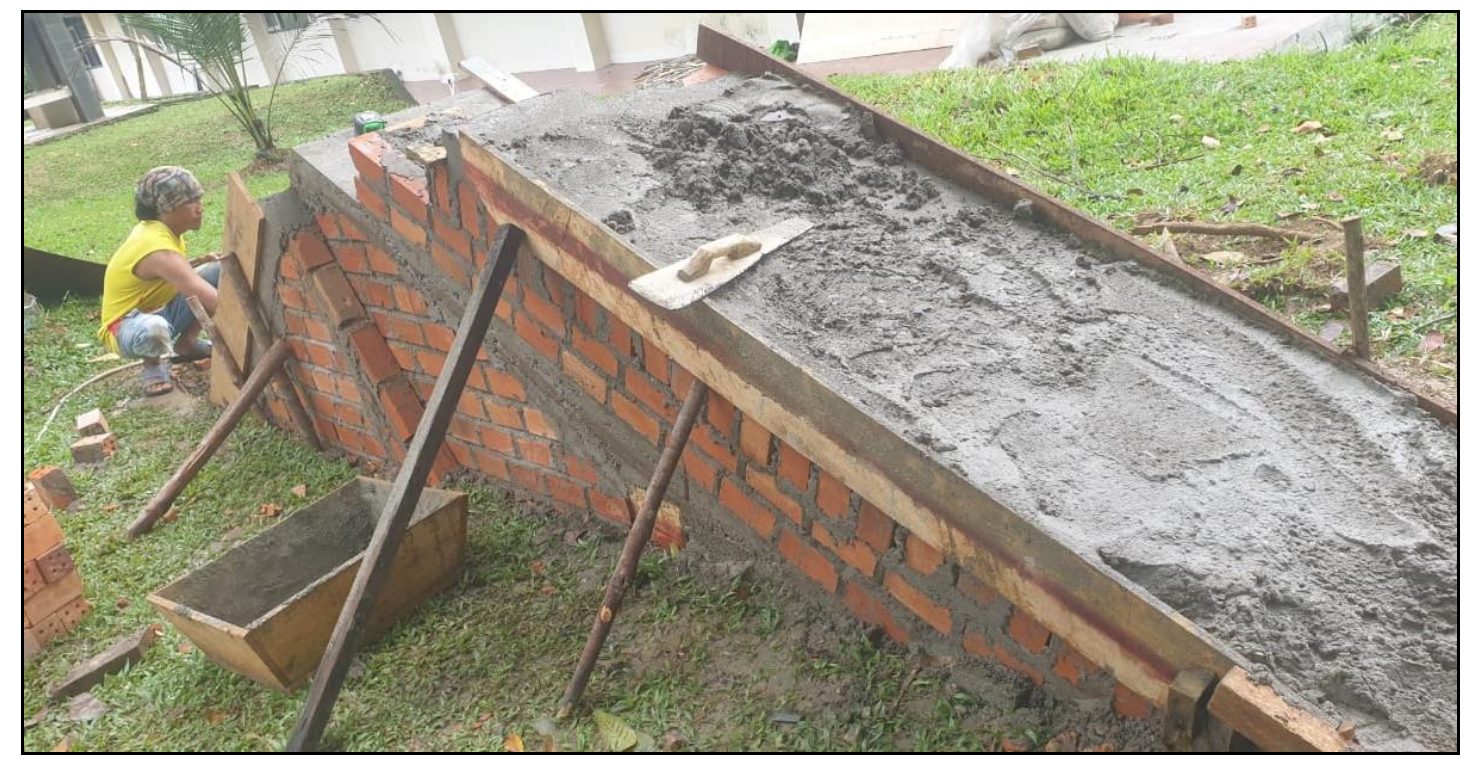

Gambar 3. Proses Pembuatan Maket Geologi Struktur Taman Bumi (Geopark) Merangin, Jambi

Tahap terakhir dari solusi yang diberikan adalah pelatihan pengukuran struktur kepada dosen dan asisten praktikum mata kuliah geologi struktur. Pelatihan ini mengikutsertakan 5 orang Asisten Praktikum Geologi Struktur dan 10 orang dosen (Kajur Teknik Kebumian, Kaprodi Teknik Geologi, Kaprodi Teknik Geofisika, Kaprodi Teknik pertambangan, dan Jajaran Dosen Jurusan Teknik Kebumian) karena tidak semua dosen di jurusan teknik kebumian berlatar belakang pendidikan teknik geologi. Kegiatan ini perlu dilakukan supaya Dosen Jurusan Teknik Kebumian dan Asisten Praktikum Geologi Struktur paham bagaimana penggunaan atau pengukuran yang dilakukan pada maket yang telah dibuat, serta dapat menjelaskan dan mendeskripsikan batuanbatuan penyusun maket geologi struktur kepada praktikan. Dari hasil pelatihan yang telah dilakukan persentase pemahaman peserta pelatihan mencapai $100 \%$, hal ini terlihat dari banyaknya peserta yang bertanya, banyaknya peserta yang berhasil menjawab setiap pertanyaan yang diajukan, dan semua peserta mampu melakukan pengukuran geologi struktur secara mandiri. Proses pengukuran instrument geologi struktur dapat dilihat pada Gambar 4.

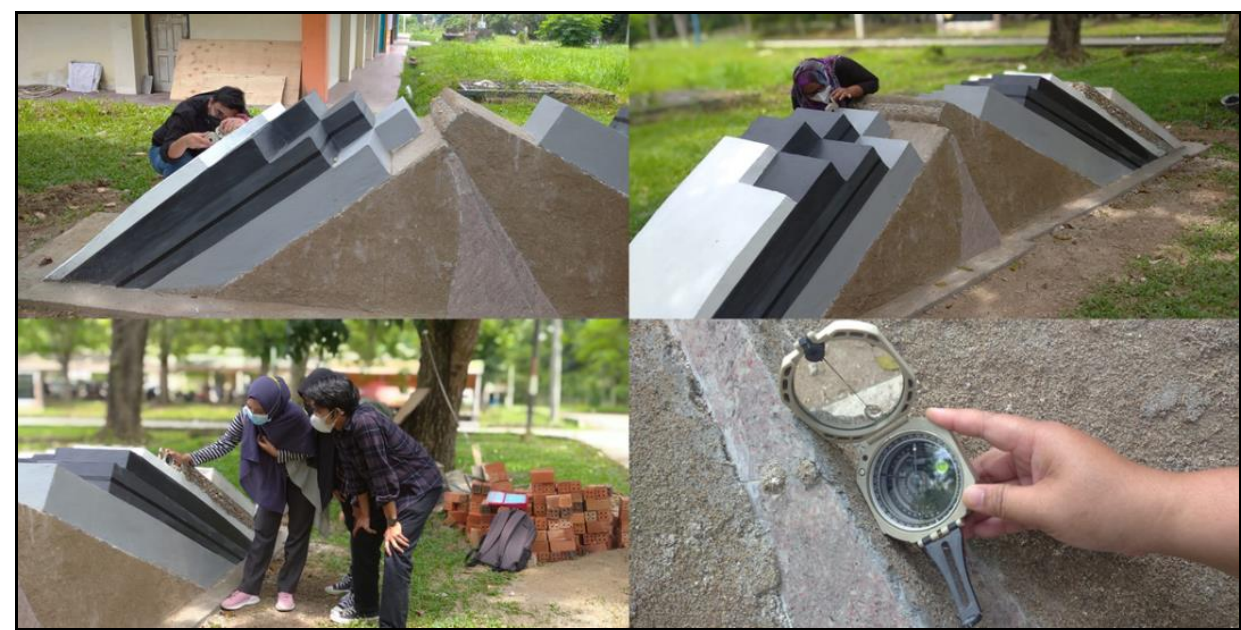

Gambar 4. Pengukuran Kedudukan Struktur Geologi menggunakan Kompas Geologi 
Berdasarkan hasil pengukuran strike \& dip didapat kedudukan pada sayap kiri lipatan maket geologi struktur berarah $\mathrm{N} 218^{\circ} \mathrm{E} / 38^{\circ}$ (Barat Daya) sedangkan pada sayap kanan lipatan maket geologi struktur berarah N $25^{\circ} \mathrm{E} / 24^{\circ}$ (Timur Laut). Dengan arah kedudukan yang saling berlawanan menunjukkan bahwa maket geologi struktur ini berbentuk antiklin. Analisis data struktur sesar dilakukan pada foot wall maket geologi yang tergerus karena pergeseran lapisan (Widagdo et al., 2017). Analisis strereografi dari data-data hasil pengukuran dapat dilihat pada Tabel 1.

Tabel 1. Hasil Analisis Data Struktur Sesar Maket Geologi Struktur Geopark Merangin

\begin{tabular}{ll}
\hline Bidang Sesar & $\mathrm{N} 42^{\circ} \mathrm{E} / 66^{\circ}$ \\
\hline Plunge/Bearing & $80^{\circ}, \mathrm{N} 87^{\circ} \mathrm{E}$ \\
\hline Rake & $45^{\circ}$ \\
\hline Nama Sesar & Sesar Mendatar Kanan \\
\hline
\end{tabular}

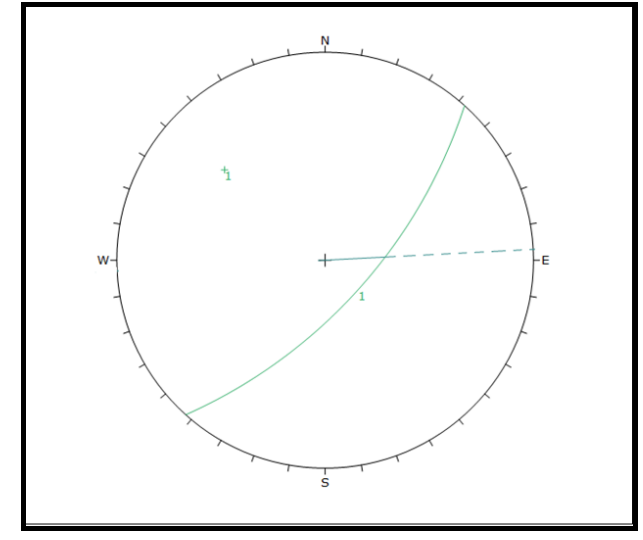

Gambar 5. Analisis Sesar Menggunakan Stereonet dengan Menggunakan Aplikasi Dips Serta Penentuan Jenis Sesar Mengacu pada Klasifikasi Rickard (1972)

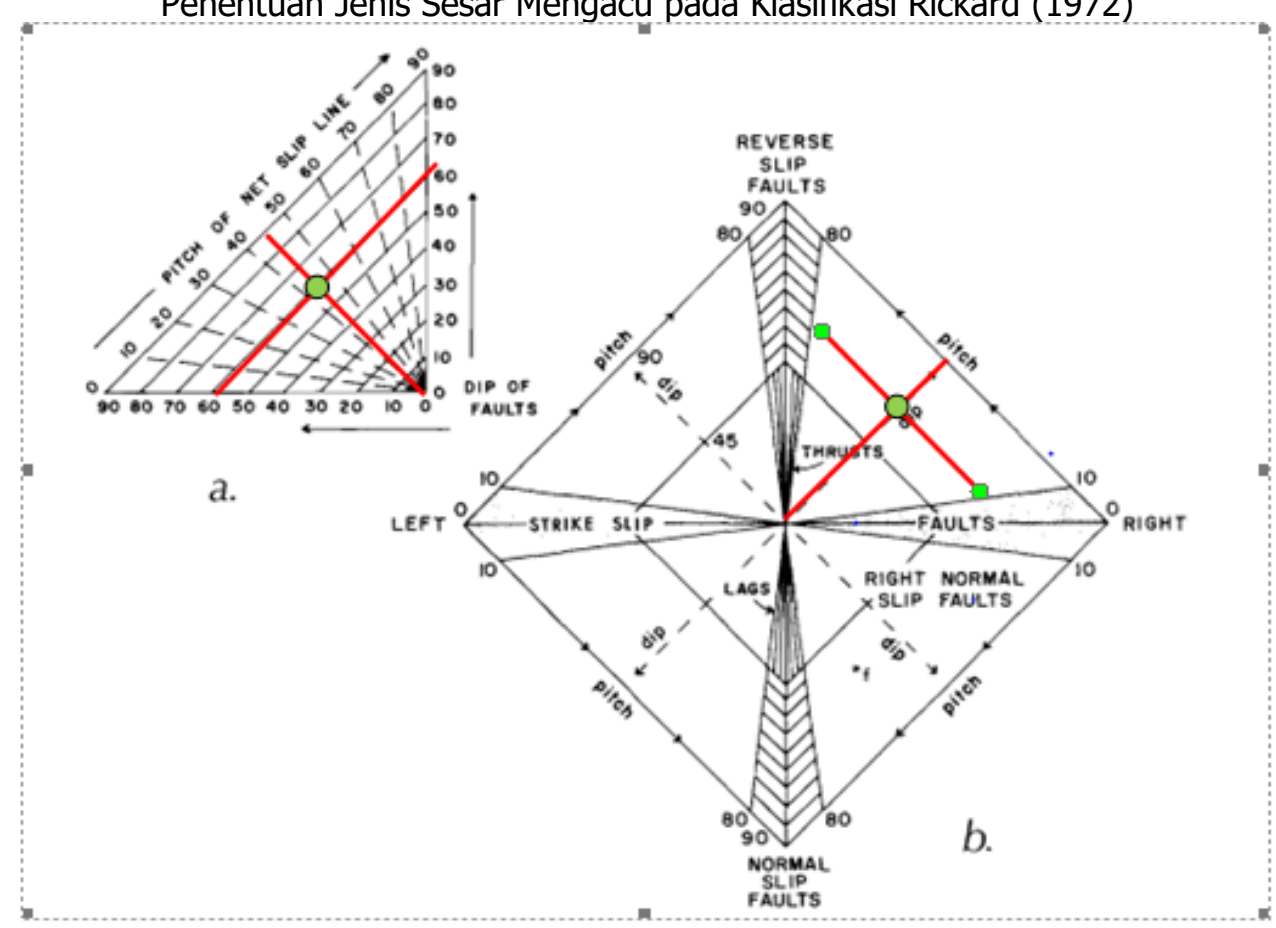

Gambar 6. Penentuan Jenis Sesar Menggunakan Klasifikasi Rickard (1972) 
Penamaan sesar berdasarkan klasifikasi Rickard (1972), dengan cara merekontruksi pergeseran sesar berdasarkan net slipnya, apakah naik atau turun dan kiri atau kanan. Kemudian data dip sesar dan rake net slip dimasukkan. Nama sesar dibaca sesuai dengan nomor yang terdapat pada kotak diagram. Berdasarkan klasifikasi Rickard (1972) nama sesarnya adalah Sesar Mendatar Naik Kanan.

\section{Kesimpulan}

Kegiatan PPM ini telah berhasil membuat Model Struktur Geologi yang merepresentasikan batuan penyusun pada Geopark Merangin. Maket ini sudah bisa digunakan sejak tanggal 1 Oktober 2021 setelah Maket diresmikan oleh Ketua Jurusan Teknik Kebumian. Maket ini cukup efektif digunakan sebagai media bantu pembelajaran dasar geologi struktur bagi mahasiswa Jurusan Teknik Kebumian. Dengan sistem pembelajaran yang mudah dipahami, mahasiswa dapat belajar cara penggunaan kompas yang baik dan benar, melakukan sketsa singkapan, mengukur arah kedudukan (strike) dan kemiringan (dip) lapisan, melakukan deskripsi batuan, profil singkapan, dan penentuan jenis sesar. Dari hasil pengukuran strike \& dip didapat kedudukan pada sayap kiri lipatan maket geologi struktur

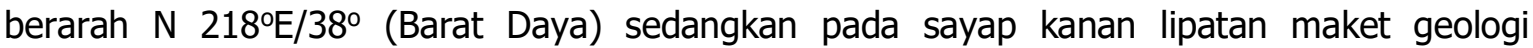
struktur berarah $\mathrm{N} 25^{\circ} \mathrm{E} / 24^{\circ}$ (Timur Laut). Maket geologi yang dibuat memiliki struktur berupa antiklin dengan bagian tengah mengalami pergeseran karena struktur sesar. Dari pembelajaran ini diharapkan mahasiswa memiliki bekal awal pengetahuan dasar pengukuran geologi struktur, sehingga akan lebih siap saat melakukan kuliah lapangan ataupun praktek lapangan.

\section{Ucapan Terima Kasih}

Ucapan terima kasih disampaikan kepada Fakultas Sains dan Teknologi, Universitas Jambi serta Jurusan Teknik Kebumian yang telah memberikan dukungan dan perizinan yang diperlukan. Kegiatan Pengabdian kepada Masyarakat ini mendapat bantuan dana dari PNBP Fakultas Sains dan Teknologi, skema Pengabdian Kepada Masyarakat Nomor: O23.17.2.677565/2021 tanggal 23 November 2020, dan Surat Perjanjian Penugasan dalam rangka pelaksanaan Pengabdian Kepada Masyarakat dengan Nomor: 662/UN21.11/PM.01.01/ SPK/2021.

\section{Referensi}

Anggreini, C., Ahman, E. and Waspada, I. (2020) 'Pengaruh Metode Problem Solving Terhadap Kemampuan Pemecahan Masalah Siswa Pada Mata Pelajaran Ekonomi Materi Pajak. Edueksos: Jurnal Pendidikan Sosial \& Ekonomi, 9(2), 80-94. doi: 10.24235/edueksos.v9i2.6347.

Azhari, A.P., Maryanto, S., Rachmansyah, A. (2016). Identifikasi Struktur Geologi Dan Pengaruhnya Terhadap Suhu Permukaan Tanah Berdasarkan Data Landsat 8 Di Lapangan Panas Bumi Blawan. Jurnal Penginderaan Jauh dan Pengolahan Data Citra Digital, 13(1), 1-12.

Davis, G. H. and Reynolds, S. J., 1996, Structural Geology of Rock and Regions: 2nd edition, John and Wiley and Sons, Inc., $776 \mathrm{p}$.

Patya, D. I., Rusdiana, D., Purwanto, C., \& Ardi, N. D. (2018). Identifikasi Struktur Geologi Bawah Permukaan Berdasarkan Nilai Suseptibillitas Magnetik Batuan Di Laut Sulawesi. Jurnal Meteorologi Klimatologi dan Geofisika, 5(1), 57-63. https://doi.org/10.36754/jmkg.v5i1.68 
Rickard, M. J. (1972). Fault classification: Discussion. Bulletin of the Geological Society of America, 83(8), 2545-2546. doi: 10.1130/0016-7606(1972)83[2545:FCD]2.0.CO;2.

Ritonga, M., Kurniantoro, E., Said, Y. M., Kurniawan, A., Mulyasari, R., \& Utama, H. W. (2018). Pemetaan objek fenomena Geologi di sepanjang Sungai Mengkarang: Guna pengembangan aset Geowisata di Geopark Mengkarang Purba, Desa Bedeng Rejo, Kabupaten Merangin, Jambi. Prosiding Semnas SINTA FT UNILA Vol. 1 Tahun 2018, 173-178.

Sunan, H. L., \& Gibran, A. K. (2020). Analisis jenis struktur geologi implikasinya terhadap bencana longsor daerah Kandangserang Kecamatan Kandangserang Kabupaten Pekalongan Jawa Tengah. Prosiding, $9(1)$.

Twiss, R. J. and Moores, E. M., (1992) Structural Geology: W. H. Freeman and Company, New York, $532 \mathrm{p}$.

Utama, H. W. et al. (2019) 'Genetic of joint system Mengkarang metapellite implication to characteristic deformation on the Muara Karing Geopark Merangin, Jambi Genetic of joint system Mengkarang metapellite: implication to characteristic deformation on the Muara Karing Geopark Me', (October). doi: 10.13140/RG.2.2.13821.31205.

Widagdo, A., Pramumijoyo, S. and Harijoko, A. (2017) 'Rekontrusi Struktur Geologi Daerah Gunung Ijo Di Pegunungan Kulon Progo-Yogyakarta Berdasarkan Sebaran Kekar, Sesar Dan Urat Kuarsa', Proceeding, Seminar Nasional Kebumian Ke-10, (September), pp. 1072-1090.

Wiratmo, L. B. (2020). Sosialisasi Pemutusan Rantai Penyebaran Covid-19 Di Kelurahan Tlogosari Kulon Kota Semarang. Jurnal Pengabdian Pada Masyarakat, 8(1), 57-65. 